\title{
Proportion Study of Wheat Flour and Purple Yam Flour and Addition of Egg on Making of Dry Noodle
}

\author{
Enny Karti Basuki Susiloningsih ${ }^{1}$, Rosida, Ariska Febrianita \\ Department of Food Technology \\ Universitas Pembangunan Nasional "Veteran" Jawa Timur \\ Surabaya, Indonesia \\ 1ennykartibasuki@gmail.com
}

\begin{abstract}
The purpose of this study was to determine the effect of the proportion of wheat flour: purple yam flour and egg addition on the quality of dried noodles produced. This study used a completely randomized design factorial pattern with 2 factors, namely the proportion of wheat flour and purple yam flour (70: 25, 60: 35, 50: 45) and 5 parts of tempeh flour and the addition of eggs $(10 \%, 15 \%, 20 \%)$, then analyzed by variance analysis, if there is a real interaction carried out the duncan test (DMRT). The results of research on dry noodles with the treatment of proportion of wheat flour : purple yam flour (70: 25) and 5 parts of tempeh flour with the addition of $20 \%$ eggs is the best treatment with a moisture content $8.99 \%$, ash content $3.17 \%$, protein content $14.29 \%$, crude fiber content $1.26 \%$, fat content $5.87 \%$, elasticity $25.26 \%$, color score 3.55 , taste score 3.1, flavor score 3.75 and texture score 3.5 .
\end{abstract}

Keywords-dry noodles, purple yam flour, tempeh flour

\section{INTRODUCTION}

The products of noodles in the form of wet noodles, dried noodles, and instant noodles have now become the second main food ingredient after rice for the people of Indonesia. Based on the results of a study of consumer preferences, noodles are the food product most often consumed by most people both as breakfast food and as a distraction [1].

Efforts to reduce the dependence of wheat flour, requires mixing some or all of the ingredients with non-flour flour as a food-making material. One choice of substitute wheat flour in making dry noodles is to replace part or all of the ingredients with purple yam flour.

Important characteristics of wheat flour that influence the texture of noodles are protein content, relative proportion between protein and starch, and the functional properties of proteins and starches in flour. Noodles whose basic ingredients and processing are simple, the physicochemical characteristics of starch and protein are likely to play a greater role in processing and product quality [2].

Besides high carbohydrate content, various studies [3] have proven that yam contains high protein but low in sugar. Its use can be mixed with wheat flour or legume flour to increase its nutritional value (composite flour).
Fortification of flour by using proteins such as soy protein, fish protein concentrate is also often carried out especially in South America. These proteins are nutritionally the desired ingredient in cereal flour, not only because they increase protein content, but also because these proteins increase levels of amino acids, especially lysine in flour [4].

Research by [5] stated that purple yam is able to substitute up to a maximum of $20 \%$ which can increase cooking loss and noodle violence. Yam is a plant that is high in carbohydrates and has bioactive compounds, namely water-soluble polysaccharides, diosgenin and dioscorin [6].

The purple yam in making noodles will reduce the stability and tenacity of the dough but increase maximum resistance, and sensory assessment shows that noodles with 5-15\% yam flour mixture are acceptable.

Tempeh flour has a high protein content and is almost equivalent to raw tempeh. The digestibility value of tempe flour has not changed even though it has undergone drying. Tempe flour also still has fiber with a level of $1.4 \%$ per gram, although less than tempeh [7].

Previous research on the addition of eggs to sweet potato dried noodles, the addition of eggs is expected to provide quality improvements in sweet potato dried noodles. Giving eggs is useful for adding flavor and nutrition, giving noodles color, adding gluten quality, and increasing the softness of noodles. Noodles that use eggs taste more savory, more supple, and elastic. The minimum use of eggs is $3-10 \%$ of the weight of flour [8].

Mixed flour (composite flour) is flour which is a mixture of flour with non-flour flour, or flour made from several kinds of cereal flour, tubers or legumes used in making noodles or other food products [9].

Yam in the field of food has been used as yam flour to replace some wheat flour in the manufacture of salted noodles. Yam flour can be used as other flour such as raw materials or noodle substitution ingredients [6].

Based on the above, this study will study the effect of substitution of wheat flour, purple yam flour, and tempeh flour and the effect of adding egg concentration on the quality of dried purple yam composite flour noodles 


\section{MATERIALS AND METHODS}

\section{A. Material}

The ingredients used in making dry noodles are purple uwi tuber, tempeh and wheat flour. The tools used were the dryer cabinet, blender, noodle mill, 80 mesh flour sieve, stove, analytical balance.

\section{B. Preparation of Purple Yam Flour}

Purple yam was washed clean, sliced into chips, soaked for 24 hours. Cut into small cubes to speed up drying. According to [10] one stage of the flour making process is drying, where the drying temperature affects swelling power, solubility and amylogafi properties of purple yam starch. Then the dried purple chips are blended / mashed, then filtered. The obtained purple flour was analyzed crude fiber, protein, fat, moisture and ash [11].

\section{Preparation of Tempeh Flour}

Tempeh is cut and blended for 10 minutes. The tempeh chips that have been dried are mashed and then filtered with an 80 mesh flour filter. Furthermore, tempeh flour was analyzed for crude fiber, protein, fat, moisture and ash [11].

\section{Preparation of Dry Noodle}

Making dry noodles is done by mixing flour and purple yam flour propotion, and tempeh flour and other supporting ingredients according to the treatment (70: 25:5, 60: 35:5, 50: 45:5) and 5 parts of tempeh flour and added eggs $(10 \%, 15 \%, 20 \%)$, stir until smooth. Then the mixture is flaked with a noodle mill and printed with a mold in the noodle mill, steamed for 15 minutes. Then the noodles are dried in a cabinet for 3 hours at $55^{\circ} \mathrm{C}$. The obtained was analyzed crude fiber, protein, fat, moisture, ash and yield [11], elasticity [12].

\section{E. Sensory Evaluation}

Twenty panelists student of Food Tecnology of Faculty Engineering Universitas Pembangunan Nasional Veteran Jawa Timur Indonesi experience in the usu and evaluation of dry noodle. They evaluated $20 \mathrm{~g}$ portions of each dry noodle samp;es using an unstructured hedonic scale 5 with ends ands anchored, 1 dislike very much and 5 like very much. The samples were presented at random and individually evaluated [13].

\section{F. Statistical Analysis}

Statistical analysis was performed by using two ways analysis of variance (Anava) and the mean were compared across group by DMRT and the significant differences were determined at $\mathrm{p}<0.05$.

\section{RESULT AND DISCUSSION}

\section{A. Composition of Raw Materials}

The compositions of raw materials vary greatly and the data presented in Table 1. The difference in the content of purple uwi flour and tempeh flour, especially protein content, can occur because of the different growth environments, the best drying temperature and quality.

TABLE I. COMPOSITIONS OF RAW MATERIALS

\begin{tabular}{|l|c|c|c|}
\hline Component (\%) & Wheat flour & $\begin{array}{c}\text { Purple yam } \\
\text { flour }\end{array}$ & Tempeh flour \\
\hline Moisture & 10.25 & 10.31 & 8.73 \\
Ash & 0.72 & 3.64 & 1.85 \\
Starch & 60.33 & 76.03 & - \\
Protein & 11.17 & 1.69 & 20.06 \\
Crude fiber & 1.10 & 1.57 & 2.40 \\
Fat & 1.60 & 0.85 & 23.15 \\
\hline
\end{tabular}

B. Yield, Moisture and Ash Dry Noodles

Yield was significantly different, moisture and ash were not significantly different. The data are presented in Table 2. The higher the proportion of purple yam flour and added eggs, the higher the yield. This is due to the addition of purple yam weight and the weight of the egg will affect the weight of the dry dough. The higher the weight of the wet dough, the higher the yield of the dried noodles produced. That is, depreciation in the product during processing decreases to bind water so that it can cause water levels to rise. Albumin on eggs causes an increase in water content in noodles [14]. Egg yolks have emulsion power so that the presence of egg yolks can lead to higher water absorption [15].

TABLE II. YIELD, MOISTURE CONTENT AND ASH DRY NOODLES

\begin{tabular}{|c|c|c|c|c|c|c|c|}
\hline $\begin{array}{c}\text { Wheat } \\
\text { flour: } \\
\text { purple } \\
\text { yam } \\
\text { flour }\end{array}$ & $\begin{array}{c}\text { Yield } \\
(\%)\end{array}$ & $\begin{array}{c}\text { Moist } \\
(\%)\end{array}$ & $\begin{array}{c}\text { Ash } \\
(\%)\end{array}$ & $\begin{array}{c}\text { Eggs } \\
(\%)\end{array}$ & $\begin{array}{c}\text { Yield } \\
(\%)\end{array}$ & $\begin{array}{c}\text { Moist } \\
(\%)\end{array}$ & $\begin{array}{c}\text { Ash } \\
(\%)\end{array}$ \\
\hline $70: 25$ & $73.43^{\mathrm{a}}$ & $8.04^{\mathrm{a}}$ & $3.26^{\mathrm{a}}$ & 10 & $71.75^{\mathrm{a}}$ & $8.15^{\mathrm{a}}$ & $3.34^{\mathrm{a}}$ \\
$60: 35$ & $73.81^{\mathrm{a}}$ & $8.35^{\mathrm{a}}$ & $3.40^{\mathrm{a}}$ & 15 & $73.77^{\mathrm{b}}$ & $8.22^{\mathrm{a}}$ & $3.51^{\mathrm{a}}$ \\
$50: 45$ & $74.39^{\mathrm{b}}$ & $8.40^{\mathrm{a}}$ & $3.55^{\mathrm{a}}$ & 20 & $76.11^{\mathrm{c}}$ & $8.42^{\mathrm{a}}$ & $3.36^{\mathrm{a}}$ \\
\hline
\end{tabular}

The more purple yam flour and eggs are added, the ash content will increase. The more flour added, the lower the ash content. The lower the ash content of flour is lower than the purple yam flour. The addition of eggs also affects the amount of ash of dried noodles, because the minerals in the eggs also play a role in the ash content of dried noodles. The greater the ash content of a food, the greater the mineral content contained in the food [16]. Products derived from animal greater ash content of a food [17].

The more purple yam flour is added, the water content decreases. The relatively high starch content in purple yam flour tends to like water (hydrophilic), causing the water content to increase. The higher the addition of eggs, the higher the moisture content of dried noodles produced. Eggs contain protein which is able contain high ash content due to the content of several minerals such as calcium, iron and phosphorus.

\section{Protein, Crude Fiber and Fat Dry Noodles}

The lower the proportion of wheat flour and the higher the proportion of purple yam flour used, the lower the protein content of dried noodles. The protein content of wheat flour is greater than purple yam flour. The higher the egg addition, the higher the protein content of dried noodles. This is because 
eggs have a fairly high protein content. Fat was significantly different, protein and crude fiber were not significantly different. The data are presented in Table 3

The more purple yam flour is added, the more crude fiber will increase. The more flour used, the average crude fiber content in dry noodles decreases, this is because wheat flour has a fairly low level of crude fiber compared to purple yam flour. The higher the addition of eggs, the lower the level of crude fiber produced by dry noodles. This is because eggs are animal additives that do not contain fiber.

TABLE III. THE PROTEIN, CRUDE FIBER AND FAT DRY NOODLES

\begin{tabular}{|c|c|c|c|c|c|c|c|}
\hline $\begin{array}{c}\text { Wheat } \\
\text { flour: } \\
\text { purple } \\
\text { yam } \\
\text { flour }\end{array}$ & $\begin{array}{c}\text { Protein } \\
(\boldsymbol{\%})\end{array}$ & $\begin{array}{c}\mathrm{C} \\
\mathbf{f i b e r} \\
(\boldsymbol{\%})\end{array}$ & $\begin{array}{c}\text { Fat } \\
(\boldsymbol{\%})\end{array}$ & $\begin{array}{c}\text { Egg } \\
(\boldsymbol{\%})\end{array}$ & $\begin{array}{c}\text { Protein } \\
(\boldsymbol{\%})\end{array}$ & $\begin{array}{c}\mathbf{C} \\
\text { fiber } \\
(\boldsymbol{\%})\end{array}$ & $\begin{array}{c}\text { Fat } \\
(\boldsymbol{\%})\end{array}$ \\
\hline $70: 25$ & $13.51^{\mathrm{a}}$ & $1.31^{\mathrm{a}}$ & $5.53^{\mathrm{a}}$ & 10 & $12.70^{\mathrm{a}}$ & $3.40^{\mathrm{a}}$ & $3.99^{\mathrm{a}}$ \\
$60: 35$ & $13.38^{\mathrm{a}}$ & $1.51^{\mathrm{a}}$ & $4.45^{\mathrm{b}}$ & 15 & $13.10^{\mathrm{a}}$ & $3.41^{\mathrm{a}}$ & $4.42^{\mathrm{ab}}$ \\
$50: 45$ & $12.60^{\mathrm{a}}$ & $1.65^{\mathrm{a}}$ & $3.23^{\mathrm{c}}$ & 20 & $13.69^{\mathrm{a}}$ & $3.38^{\mathrm{a}}$ & $4.80^{\mathrm{b}}$ \\
\hline
\end{tabular}

The more purple yam flour is added, the fat content will decrease. Conversely, the more flour added, the fat content increases, this is because the fat content in wheat flour is relatively higher than purple yam flour. The higher the addition of eggs, the higher the level of dried noodles produced.This is caused by the fat content in chicken eggs by $11.2 \%$ so that the more eggs are added, the higher the fat content. [18].

\section{Elasticity and Organoleptic Dry Noodles}

Elasticity was significantly different, taste was range from 3.05 to 3.95 , color was range from 2.75 to 3.60 , flavor range from 2.45 to 3.75 and texture was range from 2.65 to 3.75 . The data are prsented in Table 4 . The higher the proportion of purple yam flour and the lower the addition of eggs, the lower the an elasticity of the noodles. This is caused by the decreasing proportion of wheat flour in making dry noodles so that it can directly reduce the gluten content found in wheat flour so that it will reduce the elasticity of the dried noodles. On the contrary, the higher the flour in making dry noodles, the more gluten content found in wheat flour will increase the elasticity of the dried noodles. The higher the addition of eggs will cause the elasticity of the noodles to increase, because egg white can form a strong layer or good adhesion so that it can improve the texture of dried noodles. Similarly, the greater the addition of eggs will increase the elasticity of dried noodles. The function of eggs in dried noodles (with the presence of other flour substitutes) as a binder for starch molecules in wheat flour with non-flour flour so that it can help form the texture of the noodles generated [19]. The addition of eggs to making noodles to create a tough product mixture that is not easily broken [20].

TABLE IV. ELASTICITY AND ORGANOLEPTIC EXAMINATION DRY NOODLES

\begin{tabular}{|l|c|c|c|c|c|c|}
\hline $\begin{array}{c}\text { Wheat } \\
\text { flour:purple } \\
\text { yam flour }\end{array}$ & $\begin{array}{c}\text { Egg } \\
\mathbf{( \% )}\end{array}$ & $\begin{array}{c}\text { Elasticity } \\
(\boldsymbol{\%})\end{array}$ & $\begin{array}{c}\text { Taste } \\
\text { score }\end{array}$ & $\begin{array}{c}\text { Color } \\
\text { score }\end{array}$ & $\begin{array}{c}\text { Flavor } \\
\text { score }\end{array}$ & $\begin{array}{c}\text { Texture } \\
\text { score }\end{array}$ \\
\hline $70: 25$ & 10 & $22.16^{\mathrm{f}}$ & 3.05 & 3.05 & 2.80 & 3.00 \\
& 15 & $22.04^{\mathrm{f}}$ & 3.95 & 3.05 & 3.25 & 3.65 \\
\hline
\end{tabular}

\begin{tabular}{|l|c|c|c|c|c|c|}
\hline $\begin{array}{c}\text { Wheat } \\
\text { flour:purple } \\
\text { yam flour }\end{array}$ & $\begin{array}{c}\text { Egg } \\
(\boldsymbol{\%})\end{array}$ & $\begin{array}{c}\text { Elasticity } \\
(\boldsymbol{\%})\end{array}$ & $\begin{array}{c}\text { Taste } \\
\text { score }\end{array}$ & $\begin{array}{c}\text { Color } \\
\text { score }\end{array}$ & $\begin{array}{c}\text { Flavor } \\
\text { score }\end{array}$ & $\begin{array}{c}\text { Texture } \\
\text { score }\end{array}$ \\
\hline & 20 & $25.26^{\mathrm{g}}$ & 3.10 & 3.55 & 3.75 & 3.50 \\
$60: 35$ & 10 & $17.72^{\mathrm{d}}$ & 3.65 & 2.90 & 3.40 & 2.90 \\
& 15 & $18.87^{\mathrm{e}}$ & 3.70 & 3.60 & 3.70 & 3.75 \\
& 20 & $18.98^{\mathrm{e}}$ & 2.70 & 3.30 & 3.65 & 2.65 \\
$50: 45$ & 10 & $14.85^{\mathrm{a}}$ & 3.20 & 2.75 & 3.30 & 3.45 \\
& 15 & $15.39^{\mathrm{b}}$ & 3.25 & 2.75 & 2.80 & 3.25 \\
& 20 & $16.37^{\mathrm{c}}$ & 3.40 & 3.10 & 2.45 & 2.65 \\
\hline
\end{tabular}

The treatment of the proportion of wheat flour: purple yam flour: 60: 35 and the addition of 15 grams of egg produced the taste, color, flavor and texture of noodles most favored by the panelists. Purple yam flavor that was not too thick and not too bland. the use of purple yam flour affects the color of noodles. the more the proportion of purple yam flour used, the darker the color of the dried noodles produced. The flavor of purple yam that is not too thick and the flavor of the egg that is not too fishy, because in the addition of eggs as much as 20 grams of panelists tend to not like the flavor of dried noodles that have been rehydrated because they smell too fishy.

\section{CONCLUSIONS}

In each treatment the proportion of wheat flour: purple yam flour and egg addition with 5 parts tempeh flour, yield, moisture content, ash, protein, crude fiber and fat were not significantly different, while elasticity and sensory properties were significantly different. Proportion of wheat flour: purple yam flour: 65: 35 and the addition of 15 grams of eggs is the best treatment.

\section{REFERENCES}

[1] Juniawati. Optimization of the instant corn noodle processing process based on the study of consumer preferences. Jurnal Pangan dan Agroindustri. 5(4): 21-26. 2003.

[2] G.G. Huo. Asian Noodles. John Willey and Son. Inc.Hoboken. New Jersey. 2010.

[3] V. Lebot, A. Ivancic, and K. Ibrahim. The geographical distribution of alletic diversity, a practical means of preserving and using minor root crop genetic resouring. Exp. Agric. 41: 475-499. 2005.

[4] K.A. Buckle, R.A.Edwards, G.H. Fleet, and M. Worton. Food Science, Gordon and Breach Science Publishers. USA. 1987.

[5] C. Huang, P. Li, M. Yang, and C.Wang. Textural and sensory priorities of salted noodles containing purple yam flour. Food Research International Manuscript Accepted for Publication. 2011.

[6] P. Li, C. Huang, M. Yang, and C. Wang. Textural and sensory properties of salted noodles containing purple yam flour. Journal Food Research International. 47: 223-228. 2012.

[7] R. Syarief. Tempe Manufacturing Procedure. Development of Tempe Small and Medium Industries. 1996.

[8] Suyanti. Manufacture of Noodles from Various Composites of Banana, Soybeans, Mung Beans, Corn, and Purple Sweet Potatoes. Cooperation Report with the DKI Jakarta Office of Agriculture and Forestry. Jakarta. 2006.

[9] A.B. Ernie. Cassava Processing Technology. National Seminar on Increasing Cassava Value Added. Faculty of Law Agriculture UNPAD, Bandung. 1989.

[10] N.A. Aviara, M.I. Gwandzung, and M.M. Haque. Physical properties of gung seed. J. of Agr. Engg. Res. 73:105-11. 1999.

[11] AOAC. Assosiation of Official analytical Chemist. Official Method of Analysis of the Association of Official Analytical of Chemist. Arlington : The Association of Official Analytical Chemist, Inc. 2005. 
[12] S.S. Yuwono. and T. Susanto. Testing the Physical Properties of Food Unesa University Press. Surabaya. 2001.

[13] J.R. Piggott. Sensory Analysis of Foods. Second Edition. Elsivier Applied Science. London and New York. 1981.

[14] F.G. Winarno. Food and Nutrition Chemistry Eleventh Edition. Jakarta: Gramedia Main Library. 2004.

[15] Y. Risti and. A. Rahayuni. Fiber, Resillieme Levels and Acceptance of Gluten-Free wet Noodles Made from Composite Flour (Composite Flour Mocaf Flour, Tapioca and Maizena). Journal of Nutrition College. 2(4): 696-703. 2013.
[16] S.S. Nielen. Food Analysis. Kluwer Academic. Plenum Publisher. New York. 2003.

[17] R. Yuliana. Characteristics of Catfish meat (Clasing batracchus) and Catfish (Pangasius hypophtalmus) with Different Composition of Tapioca Flour (Easay) Palembang Faculty of Fisheries. PGRI University. 2013.

[18] I. Komala. Nutrition Content of Animal Husbandry Products. Student Master of Animal Science University Putra Malaysia. Malaysia. 2008.

[19] U.L. Yumna, W.S. Windrati, and N. Dimiyah. Characteristics of Dry Noodles Made from Breadfish Flour and Addition of Egg. Jurnal Agroteknologi. 11(1): 30. 2017. 